\title{
Organisational Structuration: Emergent Social Action In Committee Work
}

Grant Jones, (Email grant.jones@gsm.mq.edu.au), Macquarie University, Australia

\begin{abstract}
The concept of structuration is still under construction. After tracking its development to date, this paper asks what happens to the concept when it is applied to understanding work behaviour in an organisational context. The concept of structuration is made more elaborate by introducing a new constituent to the process, the element of preferential role. What influence, if any do the actuations of preferential roles by individuals have on the social structure and of the collective group behaviour? The paper serves as a model for anyone who seeks ways of testing the concept of structuration in practice.
\end{abstract}

The research reported in this paper suggests an answer to a practical question thrown up by the concept of structuration. Structuration is one way of resolving the opposition between those collectivists who seek to observe structure as a determinate of individual behaviour and those individualists who see group behaviour as nothing more than the sum total of individual behaviours. Anthony Giddens, who is generally credited with the formulation of the concept, provides little instruction on how to actually operationalise the concept of structuration in an empirical investigation. Great in theory; how is it studied in practice? Moreover, how can the concept be put to work in understanding the social organisation of work and its outcomes? After sketching the development of the concept of structuration, this paper reports on one attempt to study structuration as it occurs in a work setting (a house of parliament) that has particular characteristics that make it ideal for the observation of structuration in action.

The unit of work that is studied is the parliamentary committee. A single parliamentary inquiry provides a unit of work to observe, which is at once discrete and well bounded and also has a wider institutional context within which the committee fits. It also provides people to study who are both political actors (in the sense prescribed by political science) and social actors (in the sense prescribed by sociology). The parliamentary committee is an ideal group to choose to test the influence of preferential role and structuration, since it is here that structuration can be observed in a highly explicit form. Parliamentarians are not wage slaves, limited by official role descriptions and duty statements. They are out to shape structures in ways that can assist individual agendas and are expected to some extent to construct their own roles. That said, the parliamentary committee is also a work group, the structure of which is - at least in theory determined by collective agreement. Nine parliamentary committees were studied in this project. Two of those committees are cased in this paper. However, in all cases observed, structuration occurred through the interaction of two pervasive sets of forces: the corporatist dictates of party structures and the actuation of the preferential roles of committee members.

\section{The development of the concept}

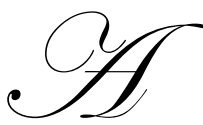

lthough Anthony Giddens is generally accredited with introducing the concept and/or its ownership, (see for example Edwards 2000; Sarker 2001; Udo and Sydow 2002;) the ideas behind structuration can arguably be traced back to Derrida's undermining of the traditional sociological certainty that social structure is fixed. This certainty implies that the only proper point to be studied is the way in which social structure reproduces itself, not the way in which it mutates. Derrida's interest in subversion through the 
undermining of hierarchy envisages a quality of "structurality." (Derrida 1978) As a quality subject to subversive action structurality is a variable.

Pierre Bourdieu's concept of "habitas" is useful in the study of political behaviour, because it treats social life as a game wherein interests compete. Actors who compete within the game must start with an appreciation of the rules. This is the position or habitas within which development to the social structure occurs as actors practice different tactics to establish competitive positioning. (Bourdieu 1981). Giddens goes onto to postulate a duality of structure and agency where each exists within the other. This is a closer identity between structure and agency than a simple mutual dependence or mutual causality. Social action exists within the rules of the game, but variations in practice change the rules, and the new rules become the context for future action.

Giddens (1984) major contribution is to begin to outline the dynamics of the social process that sees actors having an impact on the structure of the collective as they create the social dynamics within which they operate. He has elaborated the concept as manifest in two variables, the pattern of the consumption of resources and the attribution of status by individuals to other individuals and groups. Human activity in consumption of resources and in the attribution of status generates structure as much as structure creates and shapes human activity. This is a less dismal sociology, where individuals are not always the unwitting subjects of social forces, condemned to value and behave in the same predictable ways, unaware of the guiding social forces that direct them. "All social actors, no matter how lowly, have some degree of penetration of the social forms which oppress them." (Giddens 1979, 73). However, Giddens stops well short of creating a picture of the Machiavellian puppet master who can engineer particular social forces to achieve particular purposes. He sees actors as unable to directly intervene to make predetermined changes to structure, but pushes the focus of observation onto the unintended consequences of social action (Giddens 1990)

In order to study structuration by means of observation, we need to identify an observable manifestation of structuration in action. The chosen unit of analysis then becomes the interaction between members of $\mathrm{s}$ social unit at work. The concept of interaction has perhaps been most developed by Goffman (1963, 1967 and 1969). The unit of analysis here is what Goffman calls the 'encounter.' In this case two encounters present themselves for attention, the formalised behaviour of the committee in public session and the perhaps even more formalised behaviour of the MP during interview. Both can be subjected to interpretive analysis. The interactions can be presented as data and their symbolic meaning can be extracted. In addition, collective behaviour can be analysed as an artefact of social organisation and collective culture.

\section{Method}

So how do people in work groups create the structure within which they work? Gidden's has suffered the criticism that his concept of duality conflates both structure and agency, making them inherently unobservable (Archer 1995). A researcher can't see structure when they are looking for agency; similarly when the researcher looks closely at agency, structure is annihilated from the conceptual frame. In order to be studied, they must be able to be observed. In order to be observed they must have a distinct, separate and objective reality. This research then observes structure and agency through separate methodologies and then effectively places the results side by side. First members of the parliamentary committees were observed in session and the collective behaviour of the committees were typed. The individualist perspective is then adopted to interview the members as agents about the ways in which they prefer to operate and to what ends: their preferential roles.

The focus on the interaction raises the question of preferential role, since interaction can be defined by the interplay of two or more roles, where individuals are acting according to their private internal motivations. Role is not well addressed by Giddens' discussion of structuration, although he does mention the importance of "positioning" (1984 83). This is surprising given Giddens' emphasis on the ability of actors to create the structures within which they then operate. The playing of one preferred role might be expected to be assisted by the creation of a structure within which that role might be effectively played. Preferential role then has a political influence on the group that is effected through consequent transformations in it's structure. 
Nor is the concept of role a feature of the few attempts to study structuration in the kinds of groups that operate within organisations. For example, Kirby's (2002) look at structuration of work-family policies promotes communication as an active tool of structuration and hints that communication might influence role perceptions, but essentially communication is the object of analysis rather than role. Neither Sarker's (2001) examination of structuration and virtual teams, nor Edwards (2000) look at structuration and innovation, nor Callahan's (2002) discussion of emotional structuration, test the way in which preferential roles effect group structuration. Even if the actor is not aware of the unintended consequences of the actuation of their preferential role, that actor can still be expected to play their role to some effect on the structure, albeit, one that might be akin to the proverbial bull in the China Shop.

The first stage of the investigation was to identify a range of committees and committee assignments that could be studied and which represented a slice of committee life. Nine Committees in three houses of parliament were selected in order to observe effects of institutional idiosyncrasies on the spread of preferential roles and the ways in which those preferential roles might be modified by differing institutional climates.

The members of those committees, their behaviour in the wider context of committee deliberations, then became the subjects of the investigation. The selection of members and their spread across the committees is outlined in Table 1.

Before the members of individual committees were interviewed the respective committee inquiries (identified in Table 1) were observed in a manner that was as close an approximation to participant observation as is possible in such a formalised and regulated environment. The collective behaviour of the committees was characterised in preparation for comparison with the individual predispositions of members. Members were then interviewed about their approach to their work and their personal objectives as parliamentarians. They were also asked to discuss their preferences in the way they like to play their role as MPs, what they saw as the significance of the committee work to that role in general and issues of the personal meaning and purpose of their activity in the context of the enquiry studied. The aim was to seek out points of correspondence between the way in which the members see themselves, the way in which they see committees, and characteristics of the collective behaviour of the committees that they create.

The transcripts of these interviews were then analysed using NUD*IST, a relational database allowing the collection of comments on particular themes and across particular fields.

\section{The preferential roles of members}

The idea of preferential roles for parliamentarians is not new. Role descriptors have been produced in the US context by Wahlke (1962) and in the UK context by Donald Searing (1994). Searing perhaps propounded the idea of preferential role construction more forcefully and in more depth: his study of the parliament at Westminster produced a highly incisive commentary on the character of the roles that were summarised by his role descriptors. Nonetheless, the role descriptions are remarkably similar to those identified by Wahlke et al three decades before: Searing's parliament man (is like Wahlke's ritualist); Searing's constituency man (Wahlke's tribune), Searing's policy specialist (Wahlke's inventor). Searing's 'ministerial aspirant' has no direct equivalent in Wahlke's typology, but this might be put down to the difference between a Westminster and a congressional institutional structure.

However, Searing left the task having completed his role descriptions. He did not take the idea to the next stage of suggesting how the actuation of these roles could effect role relations and hence reconstruct the social structure of parliament.

The project to be reported here also adopts the technique of identifying role descriptors which describe the preferential roles of MPs. For ease of presentation the preferential roles of members that were induced from the data are reduced to five highly symbolic/descriptive labels: the parliamentarian, the political theorist, the partisan, and the constituency servant. In a short paper it is all too easy with this form of analysis to become lyrically descriptive but analytically glib. For economy of style the key features of these roles have been separated into constituent 
Table 1 - Interview Selection by Inquiry

\begin{tabular}{|l|c|c|c|}
\hline Committee & $\begin{array}{c}\text { Official Committee } \\
\text { Membership }\end{array}$ & $\begin{array}{c}\text { Members Active in } \\
\text { Each Inquiry }\end{array}$ & Interviewees \\
\hline $\begin{array}{l}\text { Australian Capital Territory (ACT) Legislative } \\
\text { Assembly Committee on the Competition Policy } \\
\text { Reform Bill }\end{array}$ & 3 & 3 & 3 \\
\hline $\begin{array}{l}\text { ACT Legislative Assembly Committee on } \\
\text { Environment and Planning }\end{array}$ & 4 & 3 & 3 \\
\hline $\begin{array}{l}\text { ACT Legislative Assembly Committee on Social } \\
\text { Policy }\end{array}$ & 3 & 10 & 8 \\
\hline $\begin{array}{l}\text { House of Representatives Committee on } \\
\text { Aboriginal and Torres Strait Islander Affairs }\end{array}$ & 14 & 10 & 9 \\
\hline $\begin{array}{l}\text { House of Representatives Committee on } \\
\text { Financial Institutions and Public Administration }\end{array}$ & 14 & 6 & 8 \\
\hline $\begin{array}{l}\text { House of Representatives Committee on Legal } \\
\text { and Constitutional Affairs }\end{array}$ & 14 & 6 & 7 \\
\hline Senate Reference Committee on Economics & 8 & 6 & 6 \\
\hline $\begin{array}{l}\text { Senate Reference Committee on the } \\
\text { Environment, Communication and the Arts }\end{array}$ & 8 & 6 & 3 \\
\hline $\begin{array}{l}\text { Senate Reference Committee on Finance and } \\
\text { Public Administration }\end{array}$ & 8 & $\mathbf{5 4}$ & $\mathbf{6 1}$ \\
\hline Members floating across inquiries & $\mathbf{7 6}$ & & 7 \\
\hline Total & & & \\
\hline
\end{tabular}

elements. Those elements have been summarised in Table 4, which is attached at the Appendix. The key features of the two roles that are most important to the specific question of structuration are provided in more detail, so that their influence on committee structure will become apparent as the committees' interactions are described.

\section{The Two Influential Roles in Detail: The Parliamentarian and the Partisan}

\section{The Parliamentarian}

Parliamentarians are members who see parliamentary processes as having an inherent value that is worth promoting and preserving. Of all the types, the parliamentarian has the strongest conception of parliamentary sovereignty and places most value on the functions that arise: e.g. representation, accountability, conflict resolution, deliberation etc. Most recognise that the realities of cabinet government and the party system subordinate the parliament to being a second class power, but they none the less strenuously defend the importance of the parliament. They advocate a flexible, open-minded approach to issues because they believe that harnessing the resources of the parliament is important if the best policy prescriptions are to be found.

The answers proposed to each new question of public interest need to be tested and evaluated against the widest possible range of evidence. Parliamentarians define the ideal process as open, consultative, investigative and advisory. They express their sense of duty to the parliament. They are there to make the parliament work.

The parliamentarian's concept of policy-making is relatively value-free in political terms in as much as it presupposes the existence of a single best solution to policy problems and supposes that agreement is a natural consequence of finding the best option. They tend to reject ideology and resist ideological socialisation.

\footnotetext{
${ }^{11}$ In addition to the official membership of the committee, any Senator is entitled to participate in any inquiry; so it is that the extra membership on the Economics and the Communications committees arises from the popularity of the issues of workplace relations and Telstra (privatisation)
} 
These parliamentarians place great value on experts and specialists for the body of knowledge that they can supply and they ascribe authority to technical knowledge. There is a conceptualisation of parliament as a collective voice of its own and an expectation that from time to time parliament will identify and put forward new facts and perspectives other than those that had been identified by the executive through its process.

\section{Parliamentarians and Committee Work}

Parliamentarians preferred mode of operation on parliamentary committees is systematic investigation. They assert that the political authority of decisions arises from the quality of the process, particularly from its rigour. They are aware that party decision-making militates against deliberative decision-making, but they seek some opportunities for the parliament to operate in a deliberative manner, despite the party system.

As such they see their role on committees as creating the conduit between the people and parliament through which information can flow towards policy making. They tend to advocate careful testing of evidence at the committee stage and see their role in both intellectual terms, as quality controllers of policy information, and representative terms in as much as they "bring the people to parliament and the parliament to the people.

The emphasis on the validity of the process as being a foundation of good decision-making is part of a general trend among parliamentarians towards reifying parliamentary process. There is an implied ethic built around the value of correct process and a need to construct a role of stewardship of the ideal parliamentary process and guardianship of the credibility of parliament. During interview, one said:

"When I'm sitting on the committee, I'm trying to convey decorum, gravitas, intelligence. I don't want the parliament to look like a bunch of yahoos. I don't want the people to think that politicians are people with their snouts in the trough and don't provide value."

\section{The Partisan}

Partisans are members who see their role within the parliament as advancing the status and influence of their particular party. They rationalise their role by arguing that, on balance, the people will be better off under their own party, and so the best thing they could do is to ensure that the party achieves and maintains power. Implicit in this mission statement is the prediction that partisans would mainly develop within parties that have a reasonable chance of attaining government, and this in fact proves to be the case. However, partisans also exist in minor parties, which seek to build themselves into larger parties and which may see a long-term future as a governing party.

This is not to say that electoral victory sees the end of their toils. They have a relationship with the electorate, but it is interpreted in terms of their duty to the party. That duty is to maintain and improve the confidence that the constituents have in them as an MP so that they can again fulfil their primary purpose at the following election by making the seat safer for the party.

Partisan expressions of identity are characterised by strong group identification. They do not have an individual role but rather a collective role. Wins are expressed as wins for the team. While the partisan understands, accepts and observes hierarchies within the party, the good of the whole is a leveller. No one is above the team. Individual strategy is not referred to as often as collective strategy. Partisans operate at one or both of two levels. At one moment they may either adopt the profile of the humble party functionary in parliament or the more combative persona of the party warrior, focused on combat with the opposing forces on the floor.

The objective of the partisan of improvement in the political position of the party is a simple and coherent mission, which makes the partisan role arguably among the most comfortable and coherent of roles. It might then be expected that there would be little ambiguity or internal tension in the partisan's role - in fact they actively pursue a resolution of such tensions, because of the special value that they place on group solidarity. 


\section{The Partisan and Committee Work}

Partisans do not regard committee work as of high priority unless it can be turned towards the key issues that separate the parties. In general, they prefer to devote themselves to internal party committees, where the discussion centres more on tactics and less on policy than is the case with the open parliamentary committees. They have little time for non-public forums that engage with members of other parties, since a hit against the other side is only of value if it translates to a reduction in the opponent's credibility with the public. Such a hit needs to get onto the news screens and into people's homes if it is to have any value, and this is a rarity in the case of committee work.

\section{Structuration of Action}

To put the collective behaviour of the committees cased below into some sort of relief and to create a baseline for evaluation of collective behaviour, consider this quotation from the Senate book of rules for parliamentary proceedings, known in Australia as "Odgers"

"It is in the conference [i.e. committee] room that careful, calm consideration can be brought to bear upon a subject, and [members] can work harmoniously in spite of party differences. It is there that the qualities and experience of the individual can be applied to matters under discussion. It is there that opportunity is provided for vision, judgment and experience to be applied and, later, brought before the Senate for open discussion and action." (Chairman of the Select Committee on the Standing Committee System, Senator R D Elliott, SD, 14/5/1931, pp. 1912-3) (Source: Odgers)

This ideal of deliberative parliamentary behaviour has great appeal to parliamentarians, but is in no way reflective of the partisan reconstructions of the meaning and purpose of committee work represented below. It might be expected then that a parliamentarian might seek to actuate his/her preferential role by trying to impose a collegiate set of social relations by encouraging civil discourse across the committee. By contrast, partisans would try to create tensions and draw factional battle lines.

Let's now turn to two salient cases to see how these expectations are confirmed or adjusted by the action. Upon investigation it turns out that committee structure is modified under the influence of an interaction of institutional pressures that create a context for the action and the actuation of preferential roles that exert themselves as pressures on committee structure. As such the two case studies below are constructed to layout these pressures and demonstrate their interaction.

\section{Case 1 - The Senate Enquiry into the partial privatisation of the State Telco.}

\section{Background}

The part privatisation of Telstra (the name of the Government owned provider of telecommunications) was a self-defining issue for the two major and opposing parties in the Australian Senate. The proposal was a key plank of the government's election platform and the government claimed to have a mandate that lent political authority to its position. The government's enthusiasm to get the bill passed is indicated by the fact that it was introduced to the parliament only two months after the election that brought the government to power. Despite the fact that the governing party had won the election in by a landslide in the House of Representatives and the authority inherent in such a mandate, it took another seven months for the bill to be passed, mainly because the Senate's move to hold a comprehensive inquiry slowed its passage. Because the Government had failed to will a majority in the Senate, the conception of the mandate proved to be a feature of the debate and the nature of the mandate proved to be contestable along party lines.

Each Senate committee exists in two parallel forms a "legislative" form and a "references" form. On the legislative form, the Government holds the majority of positions and the position of committee chair, allowing it reasonable certainty of getting its legislation a sympathetic review by the committee. The reference incarnation is 
supposed to be for review of more general questions and its majority and chair comes from the combined opposition and minor parties. The key tactical move by the opposition and minor parties was to send the bill to the 'references' incarnation, which meant that the opposition parties gained control over the construction of the process.

Of the eight committee members, four were from the Australian Labor Party (Labor), three were from the government (Liberal) party and the chair was from the Australian Democrats. Instead of the brief review process within a framework of quality control, which the government would have preferred, the bill got a thorough and fundamental critique of its direction and content. There were 647 public submissions and ten days of hearings held in major centres in the states represented by the each of the Senators.

The inquiry was thus an exercise in political opposition and the promotion of a public critique of the government from the beginning. There was never any prospect of a unified position emerging. In this light, one of the opposition senators made the unusual suggestion that, since this was to be an overtly political exercise, it would be more efficient for all concerned if the opposition and government members conducted their private meetings separately and developed their own reports rather than going through the motions of trying to develop consensus. The senator, who made this suggestion (and whose preferential role was that of the partisan) also saw a tactical significance in the fact that such agreement conferred the advantage of preventing the government from getting advance warning of the line that they were to take in their subsequent report.

\section{Behavioural Character - Competitive Partisanship}

Of all the nine inquiries examined by the project from which this paper is drawn, this one was the most acrimonious. Witnesses frequently paused in giving their evidence to watch the spectacle of debate, which erupted from time to time among committee members from opposing parties. There was also a tendency among all senators to identify witnesses as aligned with one side or the other and to attack them on that basis. Partisan attacks on the witness invariably set off tactical play as one side tried to contain the attack on their witness and the other side attempted to drive the attack home. In the following exchange a Liberal Party senator (i.e. from the governing coalition of parties) is pressing a witness by implying that her anti-privatisation position is not representative of the views of the people she claims to represent (in this case pensioners and superannuants). She asks the witness whether or not she has surveyed her membership. The witness reacts by making a political threat, highlighting the partisan nature of the conflict.

Witness: You are putting words into my mouth. I totally reject your words and your questioning. I will report it back to my membership.

Chair: Excuse me; Senator X has a point of order.

Opposition Senator \#1: The witness has clearly stated the organisation's position, so could you ask the senator to desist from this line of questioning?

Government Senator \#1: Which is no.

Witness: It is an unfair question.

Chair: Could we move on to the last question from this side? Then we have time for just two from the other side.

Government Senator \#2: Madam Chair this is a little bit irregular. We have not had an opportunity to ask questions. We have now had time chewed up with a point of order from the other side, from the witness disputing...

Opposition Senator \#2: What about the time you are chewing up with this point of order?

And later: 
Witness: I feel that Senator (government 1) and Senator (government 3) - not Senator (Government 2) because he just made a statement - were provocative to my organisation, trying to make out some negativity about my organisation. I am pleased to hear Senator (Opposition 3) talk about our credibility.

The differentiation along party lines and the political heat are represented by the chair's allusion to sides and the need to balance the rights of each. The witness's complaint suggests a tactic of each party attacking the case of the other by respectively attacking and supporting the witness. The witness is in fact a former union official and has been recognised by the government senators; her credibility is seen to be diminished because of her partisan association with the Labor Party. The use of formal points of order is relatively rare in deliberative, cooperative discussions, but tends to become more common when things get competitive.

\section{The Influence of Preferential Role}

Tables 2 and 3 show the number of members identified with each of the preferential roles types identified by the research. They show the clear numerical dominance of the partisan type on both committees.

There is a social taboo against debating issues during public meetings, which is understood in all the houses studied, but which is most strongly applied in the Senate. The taboo applies to debates between committee members and witnesses and between members of the committee. The committee's public meetings are constructed as information gathering exercises. Witnesses are seen as being available to provide information, the quality of which can be tested but not evaluated adversarially. Parliamentarians, who are concerned that public debate brings the house into disrepute and diminishes its authority with the wider population, most actively promote the taboo. Debate among members during hearings also suggests that the parties have preconceived positions, which undermines any pretence at a deliberative parliamentary process. However, there were no parliamentarians involved in the Telstra inquiry who could have exerted this kind of influence.

The committee was numerically dominated by partisans, whose interest lay in creating a fight and getting it into the press. The way in which the battle is reported becomes all-important. While the witness was indeed a partisan, the press reports of the following day ignored this aspect of the attack. With obvious delight a Labor partisan provided a copy of the coverage in the following day's national daily newspaper for this study. The headline read: 'Senators Savage Pensioner Advocate'.

Table 2 The Arrangement of Roles

\begin{tabular}{|c|c|c|c|c|}
\hline Partisan & Policy specialist & $\begin{array}{c}\text { Constituency } \\
\text { Servant }\end{array}$ & Political Theorist & Parliamentarian \\
\hline 6 & 2 & 0 & 0 & 0 \\
\hline
\end{tabular}

The heat of the competition was enhanced by the concentration of partisans on the inquiry, including some who brought a history of personal antagonism, which added to the heat generated by the issues under inquiry. A structural feature that further concentrated the partisan input was that the two policy specialists were in their first terms of office and at this early stage were effectively learning the ropes and not oriented to any form of reconstruction of the committee process.

\section{Institutional Forces}

The centrality of the issue on the government's agenda gave the committee high status in the eyes of its own members and of members participating in other inquiries. The size and weight of the community response further enhanced the status of the inquiry among MPs. 
The party-political significance of the bill was enhanced by the fact that the Labor members of the committee were from the centre left and left wing of the party, creating an ideological divide between coalition and Labor members over privatisation within the committee. Further, the issue politically divided the major parties in the sense that the affected union, the Communications, Electrical and Plumbing Union (CEPU) is an affiliated member of the Australian Labor Party.

The stakes for the Government were high at this stage. The slimmest majority (1) of senators had declared their opposition to the Bill. So at this stage of the proceedings, the inquiry was the only obvious strategy available to the government to influence the Senate to pass the bill, a fact that generated a sense of desperation. This situation pertained right up until the day before the report was due to be finalised when a Senator from the Australian Labor Party (the official opposition) resigned from the Party, altering the balance of power in the Senate, so that it was now in the hands of two senators, one independent and one newly independent. One Liberal senator explained the heat of the discourse by saying:

Until he crossed the floor, we didn't have the numbers. There was the real chance that unless we could do something fairly convincing the Bill was going to go down and the government had staked a lot on it. It was our first major test.

Compare the statement above to one made by a Labor senator participating in the same inquiry, this time in commenting on the personal significance of committee work:

These inquires don't really excite me. Now take something like (X's) defection. I couldn't believe it was happening. I was terrified but at the same time I was absolutely riveted. I could not have taken my eyes away as I watched what was happening. That changed everything.

The arrangement of institutional forces is highly indicative of the power of role construction in the case of the Telstra Inquiry, because the structure of institutional forces changed markedly when the issue of selling or not selling became suddenly contestable. However, there was no apparent behavioural change among the committee members, who continued their antagonism into the chamber debate on the bill that occurred once the committee had reported.

As with the Workplace Relations Inquiry (cased below) there was an unusually high level of media interest. However, the media coverage was exclusively focused on the Committee in the case of the Telstra Inquiry, whereas the media coverage of Workplace Relations was more diffused (see below).

The title given to the majority report - 'Telstra: to Sell or Not to Sell'- starkly set out the fundamental political ground:. This theme was picked up by the Australian Broadcasting Corporations, key current affairs programs on the night of the report's release, which provided a national television platform for the committee chair to condemn the sale of Telstra.

\section{Case 2- The Senate Economics Reference Committee Inquiry into proposed reform of Workplace Relations}

The Senate Inquiry into the Workplace Relations Bill was constructed similarly to that of the Telstra inquiry. Despite the fact that it was a legislative matter, the opposition majority sent the bill to the 'references' incarnation of the committee because of its partisan importance, giving those who opposed the bill numerical superiority. The partisan significance of this particular bill was arguably greater than was the case for the privatisation of Telstra because change to laws effecting workplace relations had been more central to the election campaign, the distributional implications effected a wider division of interests and the bill allowed direct representation of key interests important to the governing and opposition parties respectively. In effect the bill pitted the whole union movement (notionally represented by the opposition Labor party) against a wide range of employer groups (notionally represented by the governing Liberal party). The government was able to claim an even stronger mandate, because the issue had been at the dead centre of the election campaign, but again the exact nature of the mandate became a contestable proposition, disputed within the committee along partisan lines. 
In separate interviews government Senators stated that the government would have preferred the inquiry to be limited to a single day. Instead, it became something of a 'road show' around the country, which was used by the opposition to generate the maximum possible exposure of the bill. The Workplace Relations Inquiry blew out in time and committed resources to become the largest of all the inquiries studied. Far from the single day exposure to scrutiny, there were 1431 public submissions to the inquiry and 18 days of hearings. As with the Telstra Inquiry, most of the witnesses could be identified as either witnesses for the prosecution or for the defence of the bill and were treated accordingly.

\section{Behavioural Character - Civil Competitive Partisanship and Negotiation}

Although the inquiry had a competitive focus, with each side directly engaged in attacking the propositions set up by the other, it lacked the heated antagonism of the Telstra Inquiry. A more collegiate tone characterised relations between members of different parties. During the road trips, members from opposing parties dined together on occasions. At certain stages of the enquiry the atmosphere in the committee room lightened to become festive. For example, during one particular day of the Sydney hearings a demonstration of women, each bearing a single rose, assembled outside the committee room. After some peremptory negotiations between the sides, the demonstrators were allowed into the committee room, filling the air with the scent of roses.

The chief tactic of the Labor Party (opposition) contingent was to construct futuristic, worst case scenarios of labour abuse under the influence of the proposed law, while the government members tried to hose down the controversy by pointing to safeguards which would prevent the alleged abuses. Overall, the behaviour was characterised by direct engagement between the sides, during which they were both grappling with each individual issue and directly arguing points raised by the opposing side, rather than staking out of ground and grandstanding that dominated the Telstra inquiry.

For both major parties, one important prize to be contested was the position of the Australian Democrats, who held the balance of power on this issue. Labor adopted a tactic of bringing real workers forward to give evidence - e.g. migrant women working in the textiles, clothing and footwear industries. The objective was to graphically illustrate the vulnerability of these workers to exploitation.

There were some exchanges between the Democrat senators and the coalition senators about the nature of their separate mandates. The coalition senators maintained that they had a mandate located in their overwhelming win in the lower house, while the Democrats claimed that they had a mandate to adjust the bill according to their platform and that the coalition mandate (and bill) could responsibly be altered to deliver the greatest good to an even greater number. The following is an exchange between a Democrat senator and an official from the National Farmers Federation, a government, partisan witness who was supporting the government's mandate as a way of supporting the authority of the bill.

Democrat Senator: I would like to look at recommendation A on page 26. You say that the government has the clearest mandate. If one accepts the mandate argument is it your view that the mandate would be to implement only what was presented to the people in the document Better Pay for Better Work and the pre-election statements of the Prime Minister?

Witness: We believe that the mandate extends to all the pre election statements of the current Prime Minister, particularly in relation to his industrial relations speech prior to the election.

Democrat Senator: Using your own mandate argument, let us look at awards: the Prime Minister said clearly and repeatedly, 'No worker will lose any of the award entitlements'. The coalition policy says that the award will be maintained but that the party will be encouraged to restructure the awards on a more flexible basis. Nowhere did it say that the awards would be restricted to 18 matters. I put it to you that if that had been presented in the election policy in February it might have been a far more controversial campaign. In advocating that we pass the bill unamended, are you advocating that we allow the government to breach its fundamental commitment to maintain 
the award system and ensure that no worker lose any award entitlement? Since you say this is our [i.e. the Democrats'] policy surely we must focus on those two things'.

Negotiations on the bill's final form were occurring outside the committee process, although according to Democrat senators interviewed as part of this study, theses negotiations were "informed" by the inquiry process. It was also observed that all parties, including the major parties and the witnesses, tended to present the evidence to the attention of Democrats members. This suitership attested to the special status of the Democrat members in this particular case and gave them an arbitral role in proceedings. The cross committee debate also demonstrates that a unifying process of genuine intellectual exchange was occurring.

The debate cited above could be evaluated as a ritual exchange reflecting the structure of bargaining positions over the bill. That is to say, the bill would be accepted in principle but would be modified. For example, Australia has a long history of bargains between unions and employers being arbitrated and "awarded" as judgements in special industrial courts. The government wanted reduce the power of centralised arbitration by restricting the number of issues upon which the independent commission for arbitration could rule, leaving the rest to direct bargaining between employers and employees. The Democrats were able to win an expansion in the number of issues that can be arbitrated effectively giving the commission greater powers than it would have enjoyed had the government been given a free hand.

\section{The Influence of Preferential Role}

The partisans involved in this inquiry were all members with a background of managing the respective party machines' and who generally had a personal preference for negotiation over confrontation. As with the Telstra Inquiry there was a conceptual opposition, which assisted debate by structuring it around dichotomous opposites: in this case the opposition lay between an industrial relations framework and an employee relations framework.

Another answer lies in the apparent cultural unification of the committee. Although the committee could easily be differentiated along partisan lines, it is also the case that members on both sides had a considerable history in industrial relations and were working from conceptual frameworks which were at once juxtaposed in opposition to one another but also mutually understood. All of the Labor participants had come into parliament from professional roles in unions while the committee chair was a former National Industrial Officer with the largest union affiliated to the Labor Party, the Shop Distributive and Allied Industries Union (SDA). Among the coalition ranks were members with sectional support from peak organisations such as the National Farmers Federation (NFF) and various Chambers of Commerce. They were all aware of the implications of a move from an industrial relations model to an employee relations model and understood the extent to which it would emerge and the extent to which it could be resisted.

Table 3 The Arrangement of Roles

\begin{tabular}{|c|c|c|c|c|}
\hline Partisan & Policy specialist & $\begin{array}{c}\text { Constituency } \\
\text { servant }\end{array}$ & Political Theorist & Parliamentarian \\
\hline 4 & 1 & 1 & 0 & 2 \\
\hline
\end{tabular}

The Democrat participants maintained a studied, deliberative air and approached the inquiry with an open mind, which is to say that they constructed their vote as contestable and/or negotiable. The two parliamentarians also contributed to the more business-like nature of proceedings through their tendency to work through negotiation and exchange. They are members of a party, which held a balance of power and this put them in a position to negotiate. This institutional advantage supported the desire inherent in the make-up of the parliamentary type to negotiate small but significant amendments. The parliamentary persona is characterised by dignity and decorum and this has its influence in reducing the sum total of heat and antagonism. 


\section{Institutional forces}

Given that the Workplace Relations Bill was more central to the electoral concerns of both major parties, that there was a direct line between the issue and the constituency concerns of each, and that the bill was likely to directly affect the widest possible constituency base, it seems reasonable to ask why the inquiry was relatively harmonious and lacked the antagonistic displays of the Telstra Inquiry. The depth of feeling against the bill among organised labour had been amply demonstrated demonstrated by a protest outside parliament, which culminated in a riot, but this depth of feeling did not translate into serious antagonisms between the two sides as represented on the committees.

One answer lies in the unequal significance ascribed to the prize. The committee was of primary significance to the opposition party (Labor) because it gave them a platform to campaign for public support for their opposition to the bill. It also gave the Labor senators, all of whom had come into the parliament from union positions, a chance to demonstrate their support for a primary constituency. However, for the government the primary effort occurred outside the committee process through direct negotiations between the minister and the Democrats.

Thus the committee was not a focal point for dispute as had been the case with the Telstra Inquiry. A Labor senator commented that 'for the coalition members it was a pointless but necessary torture that they just had to go along with'. This comment was mirrored by complaints made by coalition senators about the fact that all of the submissions from unions seemed to be identical, coordinated by the Australian Council of Trade Unions, and with the repetition of the same position over and over again simply prolonging the process. The minister characterised the process as 'Groundhog Day', likening the inquiry to the film in which the central (played by Bill keeps reliving the events of a single day until he finally gets it right. Coalition senators characterised their position as having been sent of a 'magical mystery tour.'

As with the Telstra Inquiry, the government minority in the Senate was the most fundamental institutional force that created the structure of the inquiry and contributed to competitive antagonisms between the parties. In both cases coalition members expressed resentment, both during the hearings and in interviews, about the broad scope of the references and the fact that they had been misdirected to the reference committee rather than the legislative committee where the government held effective control and the numerical majority.

A significant structural difference to the Telstra inquiry occurred as a result of the fact that the government's mandate was accepted by the Australian Democrats, albeit with some dispute as to its exact nature. All members understood throughout the process that their was a high likelihood that the bill would pass in some form given the ongoing negotiations, which were being productively pursued in good faith from the government's point of view.

Not surprisingly then, the status ascribed to the inquiry by Labor members was high, while coalition members were more sanguine about its institutional status. None the less, the Minister for Workplace Relations had a staff member assigned to follow the inquiry, attend the hearings and keep him briefed, which indicates the ascription of some measure of strategic importance by the government to the inquiry.

Media interest was diffused, with alternative focuses in the riot that occurred outside Parliament House and other public demonstrations and the private negotiations between the Democrats and the government, which tended to make up the bulk of the 'front page' quality coverage given to the issue.

\section{Preferential role, institutional pressures and structuration}

The assumption underpinning any conception of the parliamentary institution as organic is that politicians can assert their own authority to determine their role, which is to say that the preferences that they apply in role construction are derived from the experiences and values they bring to parliament or that they develop through their experience in parliament. Implicit in the idea that politicians have control over their own individual role construction 
is a notion of politicians as both individual repositories of authority that can, and do, determine values. They are managers, who allocate their personal resources to achieve the ends dictated by their values. They also attempt to assert their role preferences in ways that direct and allocate the resources of the collective committee. This is the process that Derrida and Giddens describe as structuration, that is the reconstitution of social activity as a result of actions that are purposeful even if the consequences for the social structure might be unintended.

A primary assumption that links structuration to productivity in the case of members of parliament on committees is that they are purposeful actors. If they just blunder around they might affect structuration, but it could not be said to be a structuration based on, or resulting from, political intent. The evidence presented above supports the contention that politicians are indeed purposeful actors. All members interviewed for the study were able to make clear statements about why they were in parliament and how their operational style attempted to actuate their personal ends.

In the two cases presented here, partisan role preferences restructured the committee's internal social relations and altered the process from one of collective deliberation to one of partisan conflict. That said, it is significant that the inquiry that should have been the more adversarial of the two, given the wider institutional pressures, was modified by the actuation of the preferential; roles of the parliamentarians. The evidence presented here demonstrates that there is a distinct correspondence between the way in which the members see their roles, the significance that they ascribe to parliamentary committees, and characteristics of the collective behaviour of the committees that they create.

Moreover, they are reflective practitioners and their reflections include consideration of at least some of these relations and their significance for the generalities of parliamentary life. All members were able to make reasonably clear connections between their perceptions of the parliamentary world and their personal behaviour. Most were able to differentiate between their personal motivations and the institutional factors that shaped their behaviour, and occasionally members were able to point to clear tensions. No one was equivocal or unsure of his or her attitude and all had well-developed, clear perspectives that they could express 'off the cuff' without the need for further reflection. Whether they saw committee work in positive terms as an enabler or negative terms as a frustration, they were all able to discuss the personal meaning (or lack of it) inherent in committee work.

The application of the elements of structuration to the reconstruction of small groups has a lot to offer managers who are trying to set up groups with social dynamics consistent with a particular purpose, or those wishing to alter the structure of groups with a view to making them more operationally effective. The selection of members who prefer particular roles is going to have its effect on overall structure, but this effect will be moderated by wider institutional pressures, which shape both the deployment of individual preferential roles and the total structure and behaviour of the group. The addition of role to the catalogue of observable variables effecting structuration gives managers a tool, which can be assessed and controlled with relative ease.

\section{References}

1. Archer M Realist Social Theory: the morphogenetic approach, Cambridge University Press, Cambridge

2. Bourdieu P. (1981) The genesis of the concepts of habitus and field Soicocriticism \#2 pp11-24.

3. Callahan J (2002) Masking the need for cultural change: The effects of emotion structuration Organization Studies; Berlin Vol 23 \# 2 pp 281-297

4. Derrida J., (1978) "Structure, Sign And Play in The Discourse Of The Human Sciences" in Writing and Difference, London Routledge

5. Derrida, J. (1991) A Derrida reader : Between the Blinds, Peggy Kamuf (ed.), Columbia University Press, New York

6. Edwards T (2000) Innovation and organizational change: Developments towards an interactive process perspective Technology Analysis \& Strategic Management; Abingdon; Dec Vol 12 \# 4 pp445 - 464

7. Giddens, A. (1979) Central Problems in Social Theory : Action, Structure and Contradiction in Social Analysis, Macmillan, London 
8. Giddens, A. (1979) Central Problems in Social Theory : Action, Structure and Contradiction in Social Analysis, Macmillan, London

9. Giddens, A. (1984) The Constitution of Society: Outline of the Theory of Structruation. Polity Press, Cambridge

10. Goffman, E. (1967) Behaviour in Public Places, Free Press New York

11. Goffman, E. (1967) Interaction Ritual, Doubleday Anchor, New York

12. Goffman, E. (1969) The Presentation of Self in Everyday Life, Allen Lane, London

13. Kirby E., and Krone K., (2002) "The policy exists but you can't really use it": Communication and the structuration of work-family policies Journal of Applied Communication Research; Annandale; Feb Vol 31 \# 1 pp 50-77

14. Sarker S., Lau F., and Sahay S., (2001 Using an adapted grounded theory approach for inductive theory building about virtual team development Database for Advances in Information Systems; New York; Winter Vol $32 \# 1$ pp 38-56

15. Searing D. (1994) Westminster's World: Understanding Political Roles Harvard University Press, London

16. Wahlke, J., Eulau, H., Buchanan, W. and Leroy, F. (1962) The Legislative System, Wiley, New York 
Appendix - Summary of Role Types and Features

\begin{tabular}{|c|c|c|c|c|c|}
\hline & Objectives & Relationships & Values & Identity & Operational Preferences \\
\hline $\begin{array}{l}\text { Parliamentaria } \\
n\end{array}$ & $\begin{array}{l}\text { Manage } \\
\text { parliamentary } \\
\text { processes } \\
\text { Find best solutions } \\
\text { Gain agreement } \\
\text { Representation }\end{array}$ & $\begin{array}{l}\text { Collegiate and/or } \\
\text { transactional } \\
\text { Support executive } \\
\text { decision-making (in } \\
\text { governing party) }\end{array}$ & \begin{tabular}{|l|} 
Openness \\
Objective rationality \\
Information \\
Pragmatism \\
Responsibility \\
Consent \\
Fair dealing \\
\end{tabular} & Club Members & $\begin{array}{l}\text { Inquiry } \\
\text { Problem Solving } \\
\text { Detail collection and } \\
\text { processing into argument } \\
\text { Deliberation }\end{array}$ \\
\hline $\begin{array}{l}\text { Constituency } \\
\text { Servant }\end{array}$ & $\begin{array}{l}\text { Deliver services } \\
\text { Represent } \\
\text { constituents }\end{array}$ & $\begin{array}{l}\text { Collegiate, Transactional, } \\
\text { and/or facilitative } \\
\text { Advocacy to the executive } \\
\text { Instrumental to the } \\
\text { constituency }\end{array}$ & $\begin{array}{l}\text { Responsiveness } \\
\text { Impartiality, } \\
\text { Representation } \\
\text { Utilitarian rationality } \\
\text { Parliament as a House of } \\
\text { Resolution }\end{array}$ & $\begin{array}{l}\text { Individualists } \\
\text { Identification with } \\
\text { the constituency } \\
\text { character }\end{array}$ & $\begin{array}{l}\text { Processing community } \\
\text { views into policy } \\
\text { argument } \\
\text { Personal lobbying }\end{array}$ \\
\hline $\begin{array}{l}\text { Political } \\
\text { Theorist }\end{array}$ & $\begin{array}{l}\text { Develop and defend } \\
\text { theory } \\
\text { Attract a support } \\
\text { base }\end{array}$ & $\begin{array}{l}\text { Close relationships with } \\
\text { members of a subgroup - } \\
\text { isolation and alienation } \\
\text { from others } \\
\text { Linkages with external, } \\
\text { intellectual contributors eg } \\
\text { academics }\end{array}$ & $\begin{array}{l}\text { Reflection } \\
\text { Rationality, Intellect } \\
\text { Presentation exercised as } \\
\text { figurehead, embodying the } \\
\text { theory }\end{array}$ & $\begin{array}{l}\text { Identifies with } \\
\text { banners that have } \\
\text { power to illustrate } \\
\text { and convey the } \\
\text { theory }\end{array}$ & $\begin{array}{l}\text { Discourse about theory } \\
\text { Refinement of thinking } \\
\text { Establishing links with } \\
\text { the like minded }\end{array}$ \\
\hline Partisan & $\begin{array}{l}\text { Improve position of } \\
\text { party/faction }\end{array}$ & $\begin{array}{l}\text { Close and cohesive among } \\
\text { fellow partisans } \\
\text { Antagonistic to } \\
\text { oppositional group } \\
\text { Ambivalent to minorities }\end{array}$ & $\begin{array}{l}\text { Solidarity } \\
\text { Instinct } \\
\text { The good of the whole }\end{array}$ & Collective identity & $\begin{array}{l}\text { Publicly combative } \\
\text { Privately integrative, } \\
\text { conciliatory, managerial }\end{array}$ \\
\hline $\begin{array}{l}\text { Policy } \\
\text { Specialist }\end{array}$ & $\begin{array}{l}\text { Achieve policy } \\
\text { results } \\
\text { Build store of policy } \\
\text { expertise }\end{array}$ & $\begin{array}{l}\text { Lobbyist: tries to act as a } \\
\text { coupling point, which } \\
\text { connects interests with } \\
\text { authority figures in } \\
\text { government }\end{array}$ & $\begin{array}{l}\text { Pragmatic focus on results } \\
\text { Rich data } \\
\text { Depth of policy treatment }\end{array}$ & $\begin{array}{l}\text { Identifies with extra } \\
\text { parliamentary } \\
\text { forces including } \\
\text { professional } \\
\text { disciplines or } \\
\text { interest groups }\end{array}$ & $\begin{array}{l}\text { Maintain narrow, } \\
\text { concentrated focus } \\
\text { Develop individualised } \\
\text { tactics } \\
\text { Lobbying decision } \\
\text { makers }\end{array}$ \\
\hline
\end{tabular}


$\underline{\text { Notes }}$ 